\title{
Effects of $\mathrm{Cu}$ on plasma cortisol and cortisol secretion by adrenocortical cells of rainbow trout (Oncorhynchus mykiss)
}

\author{
Alexandra Gagnon $^{\mathrm{a}}$, Catherine Jumarie $^{\mathrm{a}}$, Alice Hontela ${ }^{\mathrm{b}, *}$ \\ a Département des Sciences Biologiques, TOXEN Research Centre, Université du Québec à Montréal, C.P. 8888, \\ Suc. Centre-ville, Montréal, Que., Canada H3C $3 P 8$ \\ ${ }^{\mathrm{b}}$ Department of Biological Sciences, University of Lethbridge, 4401 University Dr., Lethbridge, Alta., Canada T1K $3 M 4$ \\ Received 2 November 2005; received in revised form 13 February 2006; accepted 15 February 2006
}

\begin{abstract}
Fish are exposed to multiple stressors, often acting concurrently, in their environment. To evaluate the potential of $\mathrm{Cu}$ to act as a chemical stressor, rainbow trout (Oncorhynchus mykiss) were exposed to $\mathrm{Cu}$ (30 or $80 \mu \mathrm{g} / \mathrm{l})$ for 30 days in the laboratory and they were subjected to a physical stressor ( 1 min air exposure) before sampling. Physiological stress indicators in the whole fish as well as cortisol secretion by adrenocortical cells in vitro were measured. Fish exposed to $\mathrm{Cu}$ had a lower condition factor, hepatosomatic index, plasma glucose, hepatic glycogen and gill $\mathrm{Na}^{+} / \mathrm{K}^{+}$-ATPase activity compared to controls. Exposure to $\mathrm{Cu}$ did not have an effect on basal plasma cortisol (fish sampled without air exposure stress) however, the air exposure-induced increase in plasma cortisol was lower in fish exposed to $\mathrm{Cu}$. Cortisol secretion stimulated by ACTH in vitro was greater in adrenocortical cells isolated from fish exposed to $\mathrm{Cu}$ in vivo but in vitro exposure to $\mathrm{Cu}$ consistently impaired cortisol secretion. Our results indicate that $\mathrm{Cu}$ at high concentrations disrupts cortisol secretion through a direct toxic effect on adrenocortical cells while low concentrations resulting from a 30-day exposure to environmentally relevant $\mathrm{Cu}$ concentrations enhances cortisol secretion in response to ACTH in vitro.
\end{abstract}

(C) 2006 Elsevier B.V. All rights reserved.

Keywords: $\mathrm{Cu}$; Fish; Cortisol; In vitro; Acclimation; Glucose; Glycogen; $\mathrm{Na}^{+} / \mathrm{K}^{+}$-ATPase

\section{Introduction}

Copper $(\mathrm{Cu})$, an essential element for cellular metabolism, is a cofactor of redox reactions involving intracellular enzymes and proteins such as cytochrome oxidase, lysyl oxidase and superoxide dismutase. The redox nature of $\mathrm{Cu}$ is essential to cellular respiration, free-radical defence and cellular $\mathrm{Fe}$ metabolism. However, at high concentrations $\mathrm{Cu}$ becomes toxic to fish. Loss of appetite, reduced growth, ion loss, decreased aerobic scope, histological alterations in kidney and gill, and mortality are some of the manifestations of Cu toxicity (Marr et al., 1996; McGeer et al., 2000a; Handy, 2003; Mazon et al., 2004). Although $\mathrm{Cu}$ concentrations rarely exceed $3 \mu \mathrm{g} / \mathrm{l}$ in pristine waters, in polluted waters they may surpass $63 \mu \mathrm{g} / \mathrm{l}$ and reach the toxicity threshold for some fish species (Taylor et al., 2003).

There is evidence to suggest that $\mathrm{Cu}$ concentrations in the body are regulated-a characteristic compatible with the essen-

\footnotetext{
* Corresponding author.

E-mail address: alice.hontela@uleth.ca (A. Hontela).
}

tiality of this metal and its toxicity at high concentrations. Grosell et al. $(1997,1998)$ reported that Cu-acclimated fish had reduced $\mathrm{Cu}$ concentrations in plasma compared with unacclimated fish, with no apparent change in gill $\mathrm{Cu}$ uptake. The difference in $\mathrm{Cu}$ concentrations was attributed to increased hepatic clearance of the newly accumulated $\mathrm{Cu}$. Other investigators demonstrated that acclimation to $\mathrm{Cu}$ enhances tolerance to acute challenges with $\mathrm{Cu}$ and other metals, partly through metallothionein induction (Carvalho et al., 2004; van Heerden et al., 2004). Hansen et al. (2002) reported that while naïve trout suffered over $80 \%$ mortality when subjected to an acute $96 \mathrm{~h}$ challenge with $91 \mu \mathrm{g} / \mathrm{l} \mathrm{Cu}$, trout acclimated to $36 \mu \mathrm{g} / \mathrm{l} \mathrm{Cu}$ for 56 days suffered only $20 \%$ mortality when challenged. Although it is known that liver, gill and the gut are the organs that mediate acclimation to $\mathrm{Cu}$ (Kamunde et al., 2002; Niyogi and Wood, 2003), how the acclimation processes influence sensitivity to $\mathrm{Cu}$ in other tissues has not been investigated.

The hypothalamo-pituitary-interrenal (HPI) axis of fish is activated during acute exposures to stressors (Hontela, 2005), including 24-96 h exposures to relatively high (up to $100 \mu \mathrm{g} / \mathrm{l}$ ) concentrations of $\mathrm{Cu}$ (De Boeck et al., 2001; Teles et al., 2005). 
The effects of chronic $\mathrm{Cu}$ exposure on the HPI axis and related parameters are less well understood. Plasma cortisol levels increased in rainbow trout exposed to $26.9 \mu \mathrm{g} / \mathrm{l} \mathrm{Cu}$ for 3 days, however they returned to normal by day 21 (Dethloff et al., 1999a). There were no effects on plasma parameters, including plasma cortisol, at $14 \mu \mathrm{g} / \mathrm{l} \mathrm{Cu}$ (Dethloff et al., 1999b). Given the controversy regarding the protective effect of cortisol during exposure to metals (Bury et al., 1998; De Boeck et al., 2003; Mazon et al., 2004), it is important to characterize the physiological stress response to chronic $\mathrm{Cu}$ exposure in fish and determine whether pre-exposure to $\mathrm{Cu}$ protects cells against $\mathrm{Cu}$ toxicity. Cortisol secretion by adrenocortical cells of rainbow trout and yellow perch is impaired by in vitro exposure to $\mathrm{Cd}$ or Hg (Leblond and Hontela, 1999; Lacroix and Hontela, 2004) and by chronic field exposures to metals including $\mathrm{Cu}$ in lakes situated in a mining region (Lévesque et al., 2003). However, the effects of chronic waterborne or acute in vitro exposures to $\mathrm{Cu}$ on cortisol secretion by the adrenocortical cells have not yet been investigated.

Thus the objective of the present study is to evaluate the impact of chronic exposure to $\mathrm{Cu}$ on the stress-related physiological responses (plasma cortisol, glucose, thyroid hormones, hepatic glycogen and gill $\mathrm{Na}^{+} / \mathrm{K}^{+}$ATPase activity) in rainbow trout to determine whether at environmentally relevant concentrations $\mathrm{Cu}$ is recognized by the fish as a chemical stressor. To test the hypothesis the pre-exposure to $\mathrm{Cu}$ in vivo protects the adrenocortical cells against the toxic effects of an in vitro $\mathrm{Cu}$ challenge, the adrenal bioassay will be used in vitro with cells from fish chronically exposed to $\mathrm{Cu}$ in vivo.

\section{Materials and methods}

\subsection{Fish and maintenance conditions}

Juvenile rainbow trout (average body weight 88.5 \pm 7.3 ), Oncorhynchus mykiss, were obtained from a commercial fish supplier (Pisciculture Laurentienne, Québec) in April-July. Fish were held in flow-through holding tanks (6001) at $15^{\circ} \mathrm{C}$ and a 12L:12D photoperiod. The tanks were supplied with Montreal city tap water which had been dechlorinated (by activated charcoal, UV irradiation plus thiosulfate titration to remove chloramines), degassed and reoxygenated to saturation. The entire plumbing system was constructed of PVC to circumvent metal toxicity. The water conductivity was $294 \mu \mathrm{S} / \mathrm{cm}, \mathrm{pH} 7.2$, alkalinity $125 \mathrm{mg} / \mathrm{l} \mathrm{CaCO} 3$, Ca $33 \mathrm{mg} / \mathrm{l}, \mathrm{Na} 12 \mathrm{mg} / \mathrm{l}, \mathrm{K} 1.51 \mathrm{mg} / \mathrm{l}$, $\mathrm{Cl} 22 \mathrm{mg} / \mathrm{l}$ and background $\mathrm{Cu}$ at $4 \mu \mathrm{g} / \mathrm{l}$. Fish were fed Purina trout Chow daily at $7 \mathrm{~h}$ at the manufacturer's recommended rate $(10 \mathrm{~g} / \mathrm{kg}$ of fish).

\subsection{Experimental treatments}

Following acclimation, fish were exposed to $\mathrm{CuSO}_{4}$ (Fisher) through water at 0,30 and $80 \mu \mathrm{g} / \mathrm{l} \mathrm{Cu}$ for 30 days. The water $\mathrm{Cu}$ concentrations were maintained at a constant level with Mariotte bottles, test solutions were added to the tank at a flow rate of $2 \mathrm{ml} / \mathrm{min}$. The nominal concentrations of $\mathrm{CuSO}_{4}$ were fractions $(15-40 \%)$ of $200 \mu \mathrm{g} / \mathrm{l}$, the $96 \mathrm{~h} \mathrm{LC50}$ reported for rain- bow trout maintained in Montreal water (Spear and Anderson, 1975). The concentration of $30 \mu \mathrm{g} / \mathrm{l} \mathrm{Cu}$ represents environmental concentrations in some lakes in Sudbury (Ontario, Canada), an important mining area with smelting and refining complexes (Iles and Rasmussen, 2005). Water samples for $\mathrm{Cu}$ analyses were taken in the middle of the tank at days 5, 10, 20 and 30; $\mathrm{Cu}$ was measured by inductively coupled plasma atomic emission spectrophotometry (ICP-AES). Mean measured water $\mathrm{Cu}$ concentrations were within the expected range: $2.09 \pm 1.02 \mu \mathrm{g} / \mathrm{l}$ in the control tank; $28.5 \pm 2.43 \mu \mathrm{g} / \mathrm{l}$ in the $30 \mu \mathrm{g} / \mathrm{l} \mathrm{Cu}$ treatment tank, and $87.7 \pm 3.37 \mu \mathrm{g} / \mathrm{l}$ in the $80 \mu \mathrm{g} / \mathrm{l} \mathrm{Cu}$ treatment tank.

\subsection{Sampling}

One week before sampling, fish in each experimental tank were separated into two equal groups by a mesh compartment. The system of two compartments permitted sampling fish in one compartment without disturbing fish in the other compartment of the same tank (same $\mathrm{Cu}$ exposure, same treatment) and stagger the sampling over two days. Fish were sampled between $9 \mathrm{~h} 00$ and $10 \mathrm{~h} 30$ in all treatments to minimize variations in the hormonal responses caused by diel endocrine cycles.

For basal cortisol levels (sampling without the air exposure stress), all fish in one compartment were removed quickly with the net to standardize the handling procedure, and they were immediately anaesthetized with MS 222. For sampling with the air exposure stress, all fish in one compartment were removed with the net, held in the air for $1 \mathrm{~min}$ and returned to the tank to be sampled $45 \mathrm{~min}$ later. Fish were weighed, fork length was recorded, and plasma was collected for glucose and hormone analyses. Fish were then perfused through the caudal vein with $0.7 \%$ saline, in preparation for the in vitro experiments with the adrenocortical cells. Livers were dissected, weighed and frozen for glycogen and $\mathrm{Cu}$ analyses. Kidneys were dissected and frozen for $\mathrm{Cu}$ analyses and gills for $\mathrm{Na}^{+} / \mathrm{K}^{+}$-ATPase analyses. The head kidneys were dissected for the in vitro experiments (see Section 2.6).

\subsection{Analyses of $\mathrm{Cu}$}

Concentration of $\mathrm{Cu}$ were measured by inductively coupled plasma atomic emission spectrophotometry (ICP-AES) in water, and in kidney, interrenal tissue and liver, using tissue homogenates corresponding to $100 \mathrm{mg}$ dry weight, as described previously by Laflamme et al. (2000). A mass of $1 \mu \mathrm{g} / \mathrm{g}$ dry weight corresponds to approximately $0.29 \mu \mathrm{g} / \mathrm{g}$ wet weight.

\subsection{Biochemical analyses}

\subsubsection{Hormone analyses}

Plasma cortisol, T3 and T4 were assayed with commercial radioimmunoassay kits (No. 07-221102 for cortisol and No. 838 for T3, ICN Biochemicals Canada, Ltd., Montreal, Que.). The characteristics of the assays were described in Hontela et al. (1995). 


\subsubsection{Glucose and glycogen}

Plasma glucose was determined with a colometric enzymatic method using glucose oxidase (GOD-PAP) (Boehnringer Mannheim, Diagnostica). Liver glycogen was assayed with a method described in Lévesque et al. (2002). Frozen liver $(\approx 0.1 \mathrm{~g})$ was digested in $10 \% \mathrm{KOH}$ and hydrolysed with amyloglucosidase (Sigma). Glucose was then assayed with GODPAP method.

\subsection{3. $\mathrm{Na}^{+} / \mathrm{K}^{+}$-ATPase}

ATPase activity was measured with the methods described in Lévesque et al. (2003). Briefly, the gill $\mathrm{Na}^{+} / \mathrm{K}^{+}$-ATPase activity was calculated as the difference in inorganic phosphate production between the reactions in two different media (buffer A without ouabain and Buffer B with ouabain). The assay period was $30 \mathrm{~min}$ at $30^{\circ} \mathrm{C}$.

\subsection{In vitro exposure to $\mathrm{Cu}$}

Adrenocortical cell suspensions were prepared as described by Leblond and Hontela (1999). Head kidneys were dissected, digested with collagenase/dispase in Minimum Essential Medium (MEM), and the individualized cells $\left(75 \times 10^{6}\right.$ cells $\left./ \mathrm{ml}\right)$ were plated in a 96-well microplate. Cells were preincubated for $2 \mathrm{~h}$ in MEM, centrifuged, then exposed to Ringer solution with or without $\mathrm{CuSO}_{4}$ at the selected $\mathrm{Cu}$ concentration for $1 \mathrm{~h}$ at $15^{\circ} \mathrm{C}$. Following exposure to $\mathrm{Cu}$, cells were washed and stimulated with $1 \mathrm{U} / \mathrm{ml}$ ACTH in MEM, and incubated for $60 \mathrm{~min}$. Cortisol in the supernatants was determined by radioimmunoassay.

To determine in vitro the $\mathrm{EC}_{50}$ of $\mathrm{Cu}$ (the effective concentration that reduces cortisol secretion by $50 \%$ ), adrenocortical cells from control fish (not exposed to $\mathrm{Cu}$ in vivo) were exposed to various concentrations of $\mathrm{Cu}$ in vitro and cortisol secretion in response to stimulation with $\mathrm{ACTH}$ was measured. The $\mathrm{EC}_{60}$ (200 $\mu \mathrm{M} \mathrm{CuSO}_{4}$, a simple solution to prepare) was the concentration of $\mathrm{Cu}$ used in subsequent in vitro exposures of the adrenocortical cells isolated from fish exposed to waterborne $\mathrm{Cu}$ for 30 days. Cell viability was assessed by flow cytometry using the exclusion dye propidium iodide. To perform the viability test, $5 \mu \mathrm{l}$ sample from each well of the microplate was resuspended in a test tube containing $370 \mu 1$ of MEM with propidium iodide $(1 \mu \mathrm{g} / \mathrm{ml})$. Cells were analyzed using a FACscan (Becton Dickinson), equipped with an argon laser emitting at $488 \mathrm{~nm}$ and 10,000 events were analyzed for each sample. Data analyses were performed with a Consort 32 system and LYSIS-
II program. Cells viability was used to determine the $\mathrm{LC}_{50}$ of $\mathrm{Cu}$ (lethal concentration that kills $50 \%$ of cells).

\subsection{Statistical analysis}

Differences among groups were tested using one-way analysis of variance (ANOVA), followed by a Dunnett's test to compare treated groups with control or Tukey-Kramer test to compare more than two groups. Data were transformed when necessary to obtain normality. A statistical significance level of $P \leq 0.05$ was used.

\section{Results}

\subsection{Copper concentrations}

Fish exposed to 30 or $80 \mu \mathrm{g} / \mathrm{l} \mathrm{Cu}$ for 30 days had higher liver and kidney $\mathrm{Cu}$ concentrations than controls; the differences in interrenal $\mathrm{Cu}$ between the groups were not significant (Table 1). Concentrations of $\mathrm{Cu}$ were consistently (17-90-fold) higher in the liver, compared with kidney and the interrenal tissue. There was no mortality in control fish and fish exposed to $30 \mu \mathrm{g} / \mathrm{l} \mathrm{Cu}$ for 30 days, however five fishes from a total of 35 died after 5 days of exposure to $80 \mu \mathrm{g} / \mathrm{l} \mathrm{Cu}$.

\subsection{Morphological characteristics of rainbow trout}

Fish exposed to 30 and $80 \mu \mathrm{g} / \mathrm{l} \mathrm{Cu}$ for 30 days and sampled without air exposure stress had a lower condition factor (ratio weight to length) and a lower hepatosomatic index (ratio liver weight to body weight) than controls (Table 1). A similar trend was detected in fish sampled with air exposure stress but the differences were not significant (data not shown).

\subsection{Plasma cortisol, T3 and T4}

Plasma cortisol levels measured in fish sampled without air exposure stress (basal cortisol) were below $5 \mathrm{ng} / \mathrm{ml}$ in controls, indicating that fish were not stressed by removal from the tank. Exposure to 30 and $80 \mu \mathrm{g} / \mathrm{l} \mathrm{Cu}$ for 30 days had no effect on basal plasma cortisol (Fig. 1). Air exposure challenge increased plasma cortisol levels in all treatment groups but the magnitude of the increase was lessened in a $\mathrm{Cu}$ concentration-dependent pattern. Plasma T3 and T4 of fish exposed to $\mathrm{Cu}$ and sampled with or without air exposure stress were not different from their controls (data not shown). The average plasma $\mathrm{T} 3$ and $\mathrm{T} 4$ level

Table 1

Concentrations of $\mathrm{Cu}$ (mean \pm S.E., $N$ ) and gross morphology of rainbow trout exposed to 0,30 and $80 \mu \mathrm{g} / \mathrm{l} \mathrm{Cu}$ for 30 days ${ }^{\mathrm{a}}$ in the laboratory

\begin{tabular}{lcllll}
\hline Treatment & Liver $\mathrm{Cu}(\mu \mathrm{g} / \mathrm{g})$ & Interrenal $\mathrm{Cu}(\mu \mathrm{g} / \mathrm{g})$ & Kidney $\mathrm{Cu}(\mu \mathrm{g} / \mathrm{g})$ & Condition factor & Hepatosomatic index \\
\hline $\mathrm{Control}$ & $84.60 \pm 12.48(7)$ & $2.44 \pm 0.14(7)$ & $6.45 \pm 0.22(7)$ & $1.09 \pm 0.01(32)$ & $1.33 \pm 0.03(32)$ \\
$30 \mu \mathrm{g} / \mathrm{l} \mathrm{Cu}$ & $147.39 \pm 16.74(7)$ & $2.41 \pm 0.15(7)$ & $8.64 \pm 0.77^{*}(7)$ & $1.03 \pm 0.01^{*}(30)$ & $1.08 \pm 0.04^{*}(30)$ \\
$80 \mu \mathrm{g} / \mathrm{l} \mathrm{Cu}$ & $283.38 \pm 56.12^{*}(7)$ & $3.00 \pm 0.49(7)$ & $8.46 \pm 0.74^{*}(7)$ & $1.02 \pm 0.14^{*}(30)$ & $1.17 \pm 0.32(30)$ \\
\hline
\end{tabular}

\footnotetext{
${ }^{a}$ Fish were sampled without the air exposure stress.

* Indicates means significantly different from the control (Dunnett's test, $P<0.05$ ).
} 


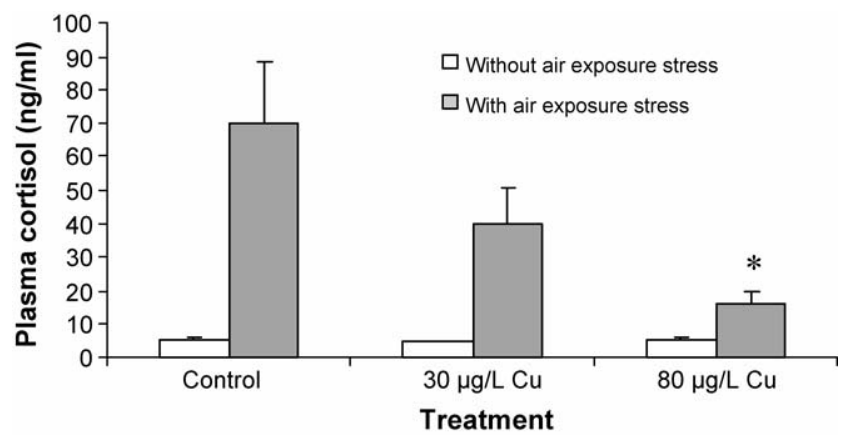

Fig. 1. Plasma cortisol levels (mean \pm S.E.) in fish exposed to 0,30 and $80 \mu \mathrm{g} / \mathrm{l}$ $\mathrm{Cu}$ for 30 days and sampled without air exposure stress (white bars, $N=30$ ) and with air exposure stress (gray bars, $N=17-20$ ). Means indicated by $*$ are significantly different from the control (Dunnett's test, $P<0.05$ ).

for all groups was $7.12 \pm 0.2 \mathrm{ng} / \mathrm{ml}$ and $15.99 \pm 0.45 \mathrm{ng} / \mathrm{ml}$, respectively.

\subsection{Plasma glucose, liver glycogen and gill $\mathrm{Na}^{+} / \mathrm{K}^{+}$ ATPase}

Plasma glucose was significantly lower, compared with controls, in fish exposed to $80 \mu \mathrm{g} / \mathrm{l} \mathrm{Cu}$ and sampled without air exposure stress (Fig. 2). There were no differences in plasma glucose in fish exposed to various concentrations of $\mathrm{Cu}$ and sampled with air exposure stress. Liver glycogen (Fig. 3A) and the activity of gill $\mathrm{Na}^{+} / \mathrm{K}^{+}$ATPase (Fig. 3B) were also lower, compared with controls, in fish exposed to 30 and $80 \mu \mathrm{g} / \mathrm{l} \mathrm{Cu}$.

\subsection{Adrenotoxicity of $\mathrm{Cu}$ and cortisol secretion in vitro}

Fig. 4 shows a dose-response curve and the toxicological characteristics of $\mathrm{Cu}$ in the in vitro bioassay using adrenocortical cells. The $\mathrm{EC}_{50}$ of $\mathrm{Cu}$ (effective concentration that reduces cortisol secretion by $50 \%$ ) is $180 \mu \mathrm{M}$ and the $\mathrm{LC}_{50}$ (lethal concentration that kills $50 \%$ of cells) is $1200 \mu \mathrm{M}$. The concentration of $200 \mu \mathrm{M}$ of $\mathrm{Cu}$ was selected for subsequent in vitro exposure experiments with adrenocortical cells isolated from control fish and fish exposed to $\mathrm{Cu}$ in vivo, sampled without or with air exposure stress.

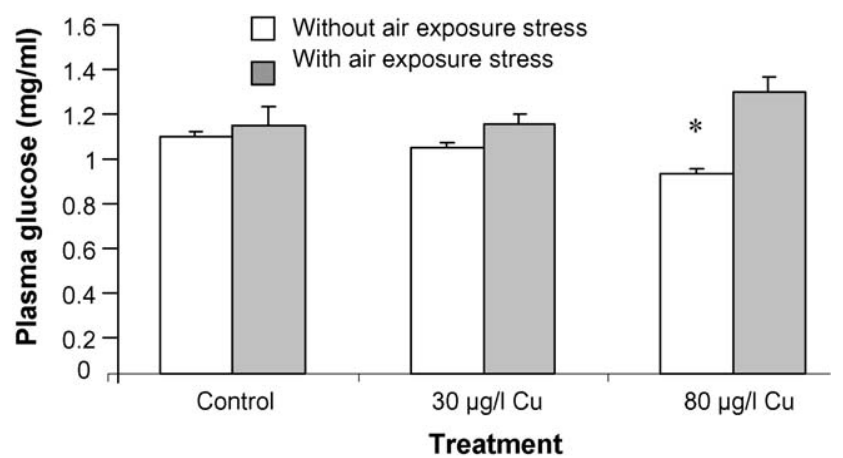

Fig. 2. Plasma glucose (mean \pm S.E.) in fish exposed to 0,30 and $80 \mu \mathrm{g} / \mathrm{l} \mathrm{Cu}$ for 30 days and sampled without air exposure stress (white bars, $N=30$ ) and with air exposure stress (gray bars, $N=17-20$ ). Means indicated by * are significantly different from the control (Dunnett's test, $P<0.05$ ).
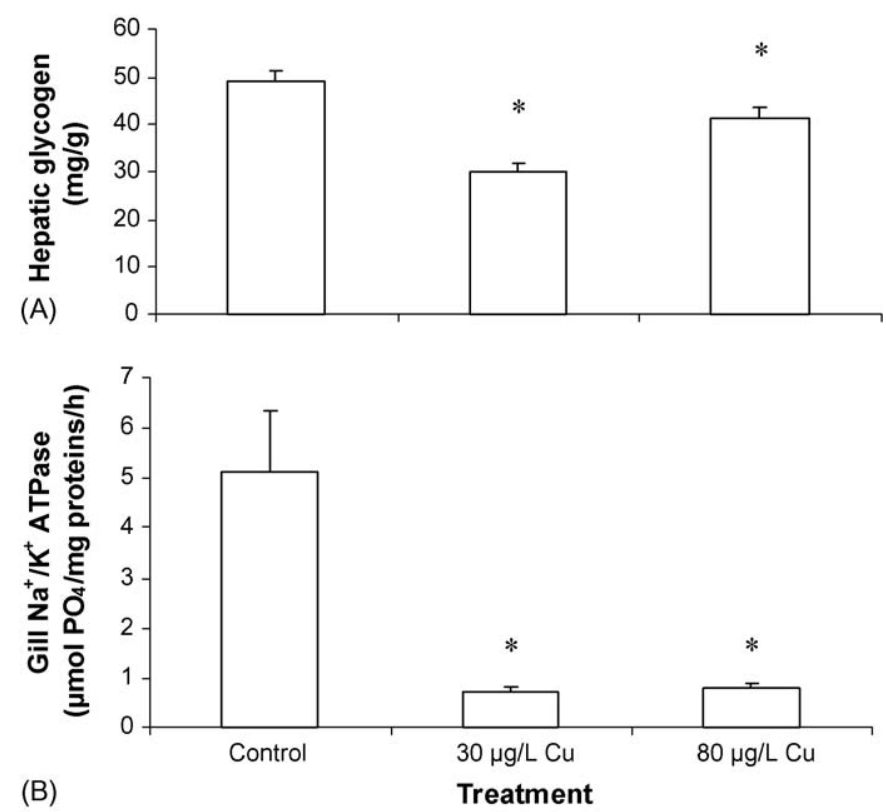

Fig. 3. Hepatic glycogen (A) and gill $\mathrm{Na}^{+} / \mathrm{K}^{+}$-ATPase activity (B) (mean \pm S.E.) in fish exposed to 0,30 and $80 \mu \mathrm{g} / \mathrm{l} \mathrm{Cu}$ for 30 days and sampled without air exposure stress. Means indicated by * are significantly different from the control (Dunnett's test, $P<0.05$ ). For each treatment, $N=30$.

In a medium without $\mathrm{Cu}$, cells isolated from fish exposed to $80 \mu \mathrm{g} / \mathrm{l} \mathrm{Cu}$ in vivo and sampled without air exposure stress secreted more cortisol in response to a standardized stimulation by ACTH $(1 \mathrm{IU} / \mathrm{ml}$ for $60 \mathrm{~min})$ than cells from control fish (not exposed to $\mathrm{Cu}$ in vivo) or cells from fish exposed to $\mathrm{Cu}$ at $30 \mu \mathrm{g} / \mathrm{l}$ (Fig. 5A). This pattern was also detected in cells isolated from fish sampled with air exposure stress (Fig. 5B), although the overall level of secretion was lower in these fish. Consistently, exposure of adrenocortical cells to $\mathrm{Cu}(200 \mu \mathrm{M}$ of $\mathrm{Cu}$ ) in vitro, reduced the $\mathrm{ACTH}$-stimulated secretion of cortisol by cells isolated from fish (controls and those exposed to $\mathrm{Cu}$ in vivo), sampled without or with air exposure stress (Fig. 5A and B).

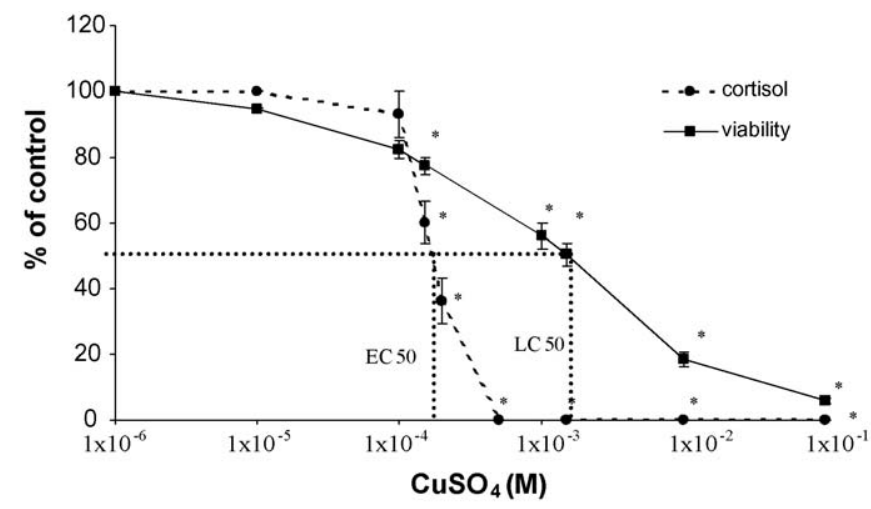

Fig. 4. Viability and cortisol secretion by adrenocortical cells (means \pm S.E.) stimulated with $1.0 \mathrm{U} / \mathrm{ml}$ ACTH following an in vitro exposure to $\mathrm{CuSO}_{4}$ for $60 \mathrm{~min}$. Means indicated by * are significantly different from controls $(100 \%)$ (Dunnett's test, $P<0.05)$. The concentration of $\mathrm{Cu}$ that reduced cortisol secretion by $50 \%\left(\mathrm{EC}_{50}\right)$ was $180 \mu \mathrm{M}$, concentration that reduced cell viability by $50 \%$ ( $\mathrm{LC}_{50}$ ) was $1200 \mu \mathrm{M}$. Adrenocortical cells obtained from the interrenal tissue of one fish correspond to $n=1$ ( $n=6$ for viability, $n=10$ for cortisol secretion). 

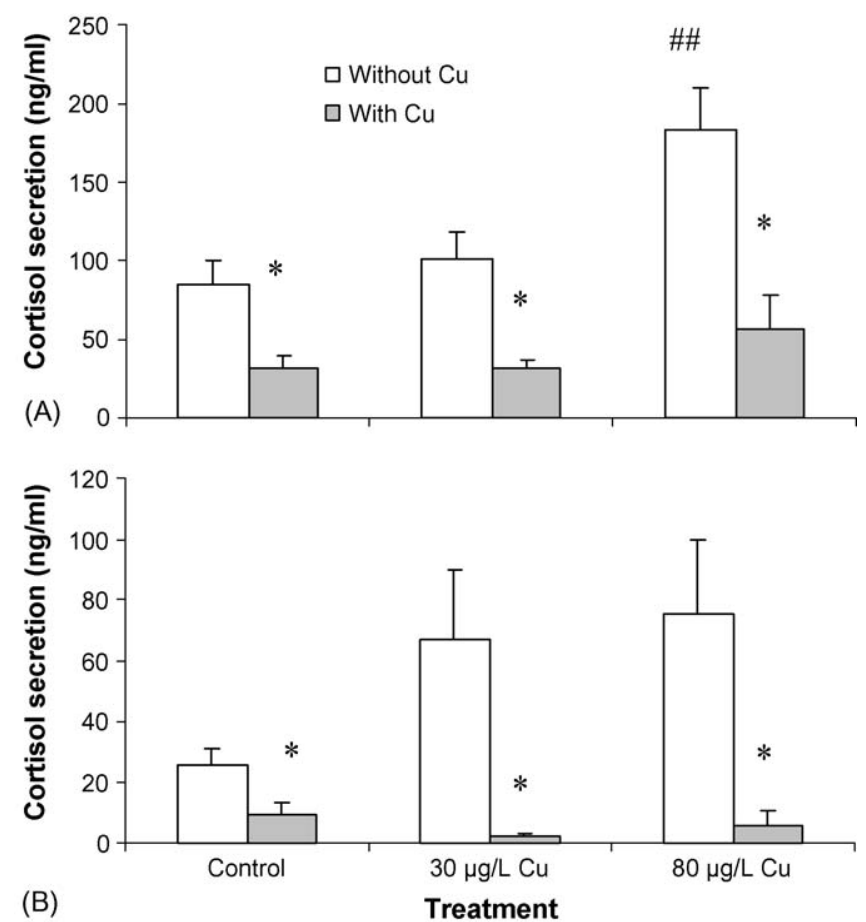

Fig. 5. Cortisol secretion (mean \pm S.E.) by adrenocortical cells stimulated with 1.0 U/ml ACTH. Adrenocortical cells isolated from fish exposed to 0, 30 and $80 \mu \mathrm{g} / \mathrm{l} \mathrm{Cu}$ for 30 days and sampled without air exposure stress (A) and with air exposure stress (B) were exposed in vitro for $60 \mathrm{~min}$ to $200 \mu \mathrm{M} \mathrm{CuSO}_{4}\left(\mathrm{EC}_{60}\right)$ (gray bars) or to saline (white bars). Mean followed by \#\# is significantly different from control treatment (Dunnett's test, $P<0.05$ ). Means with $\mathrm{Cu}$ followed by * are significantly different from means without $\mathrm{Cu}$ in same treatment (Dunnett's test, $P<0.05$ ). For fish without air exposure stress $N=15$, for fish with air exposure stress $N=11$.

\section{Discussion}

The present study was designed to evaluate the impact of $\mathrm{Cu}$ on the physiological status and the hypothalamo-pituitaryinterrenal (HPI) axis of rainbow trout, and test the hypothesis that pre-exposure to $\mathrm{Cu}$ in vivo protects cells against adverse effects of subsequent exposures to this metal. The water $\mathrm{Cu}$ concentrations used in this study were environmentally relevant and did result in accumulation of $\mathrm{Cu}$ in fish tissues. Moreover, $\mathrm{Cu}$ concentrations in livers of trout exposed to the higher concentration $(80 \mu \mathrm{g} / \mathrm{l})$ were similar to levels reported by Laflamme et al. (2000) in perch from field studies in the mining area of Abitibi, Qc. Similar to other laboratory and field studies, liver was the principal organ of $\mathrm{Cu}$ accumulation, followed by other tissues (McGeer et al., 2000b; Audet and Couture, 2003; Lévesque et al., 2003; Giguere et al., 2004).

Morphological characteristics were used in the present study, along with physiological responses, as indicators of effects of metal exposure. Numerous field studies reported that the condition factor is lower in fish exposed to mixtures of metals, through alterations of enzymatic capacity (Lévesque et al., 2003; Couture and Kumar, 2003) and in some situations, alterations of the food basis in contaminated lakes (Sherwood et al., 2000; Iles and Rasmussen, 2005). Exposure to $\mathrm{Cu}$ alone decreased the condition factor and hepatosomatic index in this study, however whether these effects were caused by reduced food consumption or a less efficient capacity to transform food into biomass was not determined. Trout exposed to $\mathrm{Cu}$ for 30 days and sampled without air exposure stress also had lower plasma glucose levels, as has been reported for other fish species (Dhanapakiam and Ramasamy, 2001), and lower liver glycogen reserves. Fish exposed to $\mathrm{Cu}$ were however able to maintain their plasma glucose as did the control fish, when challenged by air exposure stress. Exposure to $\mathrm{Cu}$ thus seems to mobilize glycogen reserves and modify glucose metabolism, possibly through a higher turnover and use of glucose by tissues challenged by $\mathrm{Cu}$. Further studies are required to characterize the effects of $\mathrm{Cu}$ on metabolic capacities of fish under controlled exposures.

Exposure to $\mathrm{Cu}$ had no effect on plasma thyroid hormone levels of rainbow trout, in contrast to studies with other fish species (Lévesque et al., 2003; Teles et al., 2005); possibly because the concentrations used in the present study ( 30 and $80 \mu \mathrm{g} / \mathrm{l}$ ) were too low to influence thyroid function in rainbow trout. In contrast, these exposures clearly decreased the activity of gill $\mathrm{Na}^{+} / \mathrm{K}^{+}$-ATPase. There is some disagreement about the effects of $\mathrm{Cu}$ on this enzyme and it has been proposed that differences in the degree of acclimation to $\mathrm{Cu}$ influence its activity (Laurén and McDonald, 1987). Acute laboratory exposure to $\mathrm{Cu}$ decreased gill $\mathrm{Na}^{+} / \mathrm{K}^{+}$-ATPase activity in common carp and rainbow trout (Laurén and McDonald, 1987; De Boeck et al., 2001). Chronic exposures however led to either a return to normal activity of the gill $\mathrm{Na}^{+} / \mathrm{K}^{+}$-ATPase (Laurén and McDonald, 1987) or an increase (McGeer et al., 2000a). Field studies with yellow perch sampled in lakes contaminated by mixtures of metals, including $\mathrm{Cu}$, reported both lower activities (Lévesque et al., 2003) and higher activities (Audet and Couture, 2003), compared to reference fish. Our results with rainbow trout exposed in the laboratory indicate that a 30 day exposure to 30 or $80 \mu \mathrm{g} / \mathrm{l}$ of $\mathrm{Cu}$ inhibits the activity of gill $\mathrm{Na}^{+} / \mathrm{K}^{+}$-ATPase, possibly because the fish were not fully acclimated to the metal.

The main objective of this study was to determine whether $\mathrm{Cu}$ at environmentally relevant concentrations is recognized by the fish as a chemical stressor and if in vivo pre-exposure to $\mathrm{Cu}$ protects cells from potentially deleterious effects of subsequent exposures. Plasma cortisol is an excellent indicator of functional alterations in the HPI axis (Hontela, 2005) and air exposure stress did increase plasma cortisol as expected. Exposure to $\mathrm{Cu}$ did not have an effect on basal plasma cortisol, however challenging the fish with air exposure stress revealed a $\mathrm{Cu}$ concentrationdependant impairment of the capacity to raise plasma cortisol. This finding is highly relevant for fish in their natural habitat where they may be subjected to multiple stimuli, including those that activate the physiological stress response. Socially subordinate fish have higher plasma cortisol levels than dominant fish and their ionoregulation is altered (Sloman et al., 2004). Exposure to metals and other toxicants that impair cortisol secretion could then influence social interactions and cortisol-dependant processes. Scott et al. (2003) reported that plasma cortisol levels in rainbow trout increased when fish were exposed to an alarm substance, a chemical released from skin epithelium, and this increase was inhibited by Cd. Other studies provided evidence that the capacity to raise plasma cortisol is impaired in 
fish exposed to organic pollutants (Aluru et al., 2004) and metals (Brodeur et al., 1997; Norris, 2000; Lévesque et al., 2002). Our data indicate that exposure to $\mathrm{Cu}$ alone disrupts the HPI axis since fish exposed to $\mathrm{Cu}$ exhibited an impaired cortisol stress response. Since this effect of $\mathrm{Cu}$ could be mediated through a decreased synthesis of pituitary ACTH, the hormone that stimulates cortisol secretion, or through a direct toxic effect of $\mathrm{Cu}$ on the interrenal steroidogenic cells, the in vitro approach was used to further investigate the mechanisms of endocrine toxicity of $\mathrm{Cu}$.

First, the toxicological characteristics of $\mathrm{Cu}$ were determined in vitro as adrenotoxicity, defined as loss of capacity to secrete cortisol in vitro $\left(\mathrm{EC}_{50}=180 \mu \mathrm{M}\right)$, and cytotoxicity defined as the capacity to kill cells $\left(\mathrm{LC}_{50}=1200 \mu \mathrm{M}\right)$. Comparing with other toxicants investigated previously (Leblond and Hontela, 1999), toxicity of $\mathrm{Cu}$ (as $\mathrm{CuSO}_{4}$ ) was lower than that of $\mathrm{HgCl}_{2}$ but higher than $\mathrm{ZnCl}_{2}$ and $\mathrm{CdCl}_{2}$. The ratio LC50/EC50 of $\mathrm{Cu}$ was 6.6, indicating that the endocrine disrupting effects occur at substantially lower concentrations than those causing cell death. To investigate the effect of in vivo pre-exposure to $\mathrm{Cu}$ on the subsequent response to the metal in vitro, adrenocortical cells isolated from fish exposed to waterborne $\mathrm{Cu}$ for 30 days were exposed for $60 \mathrm{~min}$ to $\mathrm{Cu}\left(\mathrm{EC}_{60}=200 \mu \mathrm{M}\right.$ of $\left.\mathrm{CuSO}_{4}\right)$ in vitro and their capacity to secrete cortisol in response to a standard stimulation by synthetic ACTH was then assessed. Cells isolated from fish exposed to waterborne $\mathrm{Cu}$ secreted more cortisol in response to ACTH in vitro than cells from control fish. This pattern was observed for fish sampled with air exposure stress (Fig. 5A) or without (Fig. 5B), although cells isolated from fish stressed by air exposure secreted overall less cortisol (maximum $80 \mathrm{ng} / \mathrm{ml}$ ) compared to about $200 \mathrm{ng} / \mathrm{ml}$ in fish sampled without air exposure stress, as has been reported by others (Rotlland et al., 2003). Thus even though the capacity to elevate plasma cortisol in response to air exposure stress was impaired by the 30-day exposure to $\mathrm{Cu}$, as was observed with whole fish in vivo, the adrenocortical cells were not impaired by this exposure, their capacity to respond to a stimulation by ACTH was in fact enhanced. A mechanism of $\mathrm{Cu}$ toxicity compatible with the in vitro and in vivo results in the present study is a disruptive effect of $\mathrm{Cu}$ on pituitary ACTH secretion. A Cu-induced decrease in ACTH secretion would result in lower plasma cortisol levels in response to air exposure stress in fish exposed to $\mathrm{Cu}$, with a normal or even enhanced steroidogenic capacity of the interrenal tissue. It is not known at present whether the effect of $\mathrm{Cu}$ on the steroidogenic capacity of the interrenal tissue is mediated through effects on the ACTH receptors and their sensitivity or numbers, or through alterations in plasma ACTH dynamics.

The influence of the in vivo pre-exposure to $\mathrm{Cu}$ on the sensitivity of the interrenal tissue to a subsequent in vitro exposure to the same metal was investigated next. Although several studies investigated the acclimation process, using for example survival parameters (Hansen et al., 2002), this study is first to address the issue of acclimation to a metal in fish endocrine cells. When cells were exposed in vitro to $\mathrm{Cu}$, cortisol secretion was reduced in fish from all the in vivo treatments, in controls and in fish pre-exposed to $\mathrm{Cu}$ for 30 days. Thus exposure to $\mathrm{Cu}$ in vivo did not protect the cells from the effects of $\mathrm{Cu}$ in vitro. The reduc- tion in cortisol secretion when $\mathrm{Cu}$ was added to the incubation media was expected to be $60 \%$ since the EC60 (200 $\left.\mu \mathrm{M} \mathrm{CuSO}_{4}\right)$, identified by the in vitro dose-response study, was used. Such a decrease was observed in control fish (not exposed to waterborne $\mathrm{Cu}$ in vivo) sampled either without or with air exposure stress. An even greater decrease in cortisol secretion in response to the in vitro exposure to $\mathrm{Cu}$ was observed in cells from fish exposed to $\mathrm{Cu}$ in vivo. Cells from fish challenged by the air exposure stress (Fig. 5B) were particularly vulnerable to $\mathrm{Cu}$ in vitro, as indicated by more than $95 \%$ reduction in their secretory capacity. Even though the $\mathrm{Cu}$ concentration chosen for the in vitro exposure $\left(200 \mu \mathrm{M} \mathrm{CuSO}_{4}\right)$ is high compared to plasma $\mathrm{Cu}$ levels measured in fish exposed to waterborne $\mathrm{Cu}$ in other laboratory studies (Grosell et al., 1997, 2001), our results indicate that $\mathrm{Cu}$ does have the potential for adrenotoxicity when it is directly available to the adrenocortical cells. Moreover, our study provides evidence that additional stressors (e.g. air exposure) render these cells even more vulnerable to $\mathrm{Cu}$ toxicity and that exposure to environmentally relevant waterborne $\mathrm{Cu}$ concentrations do not protect the adrenocortical cells against $\mathrm{Cu}$ toxicity in vitro.

In conclusion, the present study provided evidence that exposure to waterborne $\mathrm{Cu}$ for 30 days impairs the capacity to elevate plasma cortisol in rainbow trout but does not disrupt, in fact enhances, the secretory response of the interrenal tissue to stimulation by ACTH in vitro. These results are compatible with the hypothesis that prolonged exposure to waterborne $\mathrm{Cu}$ at concentrations that did not lead to a detectable accumulation in the interrenal tissue, may impair pituitary ACTH secretion. Our study also provided evidence that $\mathrm{Cu}$ does have an adrenotoxic potential since exposure to $\mathrm{Cu}$ in vitro impaired the secretory capacity of the adrenocortical cells. Pre-exposure to waterborne $\mathrm{Cu}$ did not protect the adrenocortical cells from $\mathrm{Cu}$ toxicity and air exposure stress together with in vitro exposure to $\mathrm{Cu}$ increased the vulnerability of the cells. Our study provides evidence that fish subjected to a metal-induced stress may not be able to respond to additional stressors imposed upon them. Fish exhibiting an impaired cortisol stress response may be at a disadvantage in coping with environmental stressors.

\section{Acknowledgments}

We thank V. Leblond, and M. Camiré for laboratory help. We also thank S. Prémont for metal analyses (INRS-ETE University of Quebec). This study was funded by MITE-RN (Impacts) and FCAR bursary to AG.

\section{References}

Aluru, N., Jorgensen, E.H., Maule, A., Vijayan, M.M., 2004. PCB disruption of the hypothalamo-pituitary-interrenal axis involves brain glucocorticoid receptor downregulation in anadromous Arctic charr. Am. J. Physiol. 287, R787-R793.

Audet, D., Couture, P., 2003. Seasonal variation in tissue metabolic capacities of yellow perch (Perca flavescens) from clean and metal-contaminated environments. Can. J. Fish. Sci. 60, 269-278.

Brodeur, J.C., Sherwood, G., Rasmussen, J.B., Hontela, A., 1997. Impaired cortisol secretion in yellow perch (Perca flavescens) from lakes contam- 
inated by heavy metals: in vivo and in vitro assessment. Can. J. Fish Aquat. Sci. 54, 2752-2758.

Bury, N.R., Jie, L., Flik, G., Lock, R.A., Wendelaar Bonga, S.E., 1998. Cortisol protects against copper induced necrosis and promotes apoptosis in fish chloride cells in vitro. Aquat. Toxicol. 40, 193-202.

Carvalho, C.D., de Araujo, H.S.S., Fernandes, M.N., 2004. Hepatic metallothionein in a teleost (Prochilodus scrofa) exposed to copper at $\mathrm{pH} 4.5$ and $\mathrm{pH}$ 8.0. Comp. Biochem Physiol. B 137, 225-234.

Couture, P., Kumar, P.R., 2003. Impairment of metabolic capacities in copper and cadmium contaminated wild yellow perch (Perca flavescens). Aquat. Toxicol. 64, 107-120.

De Boeck, G., Vlaeminck, A., Balm, P.H.M., Lock, R.A.C., de Wachter, B., Blust, R., 2001. Morphological and metabolic changes in common carp, Cyprinus carpio, during short-term copper exposure: interactions between $\mathrm{Cu}^{2+}$ and plasma cortisol elevation. Environ. Toxicol. Chem. 20, 374-381.

De Boeck, G., de Wachter, B., Vlaeminck, A., Blust, R., 2003. Effect of cortisol treatment and/or sublethal copper exposure on copper uptake and heat shock protein levels in common carp, Cyprinus carpio. Environ. Toxicol. Chem. 22, 1122-1126.

Dethloff, G.M., Schlenk, D., Khan, S., Bailey, H.C., 1999a. The effects of copper on blood and biochemical parameters of rainbow trout (Oncorhynchus mykiss). Arch. Environ. Contam. Toxicol. 36, 415-423.

Dethloff, G.M., Schlenk, D., Hamm, J.T., Bailey, H.C., 1999b. Alterations in physiological parameters of rainbow trout (Oncorhynchus mykiss) with exposure to copper and copper/zinc mixtures. Ecotoxicol. Environ. Saf. $42,253-264$

Dhanapakiam, P., Ramasamy, V.K., 2001. Toxic effects of copper and zinc mixtures on some haematological and biochemical parameters in common carp, Cyprinus carpio (Linn). J. Environ. Biol. 22, 105-111.

Giguere, A., Campbell, P.G.C., Hare, L., McDonald, D.G., Rasmussen, J.B., 2004. Influence of lake chemistry and fish age on cadmium, copper, and zinc concentrations in various organs of indigenous yellow perch (Perca flavescens). Can. J. Fish. Aquat. Sci. 61, 1702-1716.

Grosell, M.H., Hogstrand, C., Wood, C.M., 1997. Cu uptake and turnover in both $\mathrm{Cu}$-acclimated and non-acclimated rainbow trout (Oncorhynchus mykiss). Aquat. Toxicol. 38, 257-276.

Grosell, M.H., Hogstrand, C., Wood, C.M., 1998. Renal $\mathrm{Cu}$ and Na excretion and hepatic $\mathrm{Cu}$ metabolism in both acclimated and non acclimated rainbow trout (Oncorhynchus mykiss). Aquat. Toxicol. 40, 275-291.

Grosell, M., McGeer, J.C., Wood, C.M., 2001. Plasma copper clearance and biliary copper excretion are stimulated in copper-acclimated trout. Am. J. Physiol. Regulat. Integr. Comp. Physiol. 280, R796-R806.

Handy, R.D., 2003. Chronic effects of copper exposure versus endocrine toxicity: two sides of the same toxicological process? Comp. Biochem. Physiol. A 135, 25-38.

Hansen, J.A., Lipton, J., Welsh, P.G., Morris, J., Cacela, D., Suedkamp, M.J., 2002. Relationship between exposure duration, tissue residues, growth, and mortality in rainbow trout (Oncorhynchus mykiss) juveniles subchronically exposed to copper. Aquat. Toxicol. 58, 175-188.

Hontela, A., 2005. Adrenal toxicology: environmental pollutants and the HPI axis. In: Mommsen, T.P., Moon, T.W. (Eds.), Biochemistry and Molecular Biology of Fishes, vol. 6. Elsevier B.V., pp. 331-363.

Hontela, A., Dumont, P., Duclos, D., Fortin, R., 1995. Endocrine and metabolic dysfunction in yellow perch, Perca flavescens, exposed to organic contaminants and heavy metals in the St. Lawrence River. Environ. Toxicol. Chem. 14, 725-731.

Iles, A., Rasmussen, J.B., 2005. Indirect effects of metal contamination on bioenergetics of yellow perch (Perca fjlavescens) in Sudbury area lakes resulting from food web simplification. Fresh Water Biol. 50, 976-992.

Kamunde, C., Clayton, C., Wood, C.M., 2002. Waterborne vs. dietary copper uptake in rainbow trout and the effects of previous waterborne copper exposure. Am. J. Physiol. 283, R69-R78.

Lacroix, A., Hontela, A., 2004. A comparative assessment of the adrenotoxic effects of cadmium in two teleost species, rainbow trout, Oncorhynchus mykiss, and yellow perch, Perca flavescens. Aquat. Toxicol. 67, 13-21.
Laflamme, J.S., Couillard, Y., Campbell, P.G.C., Hontela, A., 2000. Interrenal metallothionein and cortisol secretion in relation to $\mathrm{Cd}, \mathrm{Cu}$ and $\mathrm{Zn}$ exposure in yellow perch, Perca flavescens, from Abitibi lakes. Can. J. Fish. Aquat. Sci. 57, 1692-1700.

Laurén, D.J., McDonald, D.G., 1987. Acclimation to copper by rainbow trout, Salmo gairdneri: biochemistry. Can. J. Fish. Aquat. Sci. 44, 105-111.

Leblond, V.S., Hontela, A., 1999. Effects of in vitro exposures to cadmium, mercury, zinc, and 1-(2-chlorophenyl)-1-(4-chlorophenyl)-2,2dichloroethane on steroidogenesis by dispersed interrenal cells of rainbow trout (Oncorhynchus mykiss). Toxicol. Appl. Pharmacol. 157, 16-22.

Lévesque, H., Moon, T.W., Campbell, P.G.C., Hontela, A., 2002. Seasonal variation in carbohydrate and lipid metabolism of cortisol-impaired metalexposed yellow perch (Perca flavescens). Aquat. Toxicol. 60, 257-267.

Lévesque, H.M., Dorval, J., Van Der Kraak, G.J., Campbell, P.G.C., Hontela, A., 2003. Hormonal, morphological and physiological responses of yellow perch (Perca flavescens) to chronic environmental metal exposures. J. Toxicol. Environ. 66, 87-106

Marr, J.C.A., Lipton, J., Cacela, D., Hansen, J.A., Bergman, H.L., Meyer, J.S., Hogstrand, C., 1996. Relationship between copper exposure duration, tissue copper concentration, and rainbow trout growth. Aquat. Toxicol. 36, $17-30$.

Mazon, A.F., Nolan, D.T., Lock, R.A.C., Fernandes, M.N., Wendelaar Bonga, S.E., 2004. A short-term in vitro gill culture system to study the effects of toxic (copper) and non-toxic (cortisol) stressors on the rainbow trout, Oncorhynchus mykiss (W.). Toxicol. In Vitro 18, 691-701.

McGeer, C.J., Szbedinszky, C., McDonald, D.G., Wood, C.M., 2000a. Effects of chronic sublethal exposure to waterborne $\mathrm{Cu}, \mathrm{Cd}$ or $\mathrm{Zn}$ in rainbow trout. 1. Iono-regulatory disturbance and metabolic costs. Aquat. Toxicol. $50,231-243$.

McGeer, C.J., Szbedinszky, C., McDonald, D.G., Wood, C.M., 2000b. Effects of chronic sublethal exposure to waterborne $\mathrm{Cu}, \mathrm{Cd}$ or $\mathrm{Zn}$ in rainbow trout. 2. Tissue specific metal accumulation. Aquat. Toxicol. 50, 245-256.

Niyogi, S., Wood, C.M., 2003. Effects of chronic waterborne and dietary metal exposure on gill metal-binding: implications for the biotic ligand model. Human Ecol. Risk Assess. 9, 813-846.

Norris, O.D., 2000. Endocrine disruptors of the stress axis in natural populations: How can we tell? Am. Zoolog. 40, 393-401.

Rotlland, J., Ruane, N.M., Caballero, M.J., Montero, D., Tort, L., 2003. Response to confinement in sea bass (Dicentrachus labrax) is characterized by an increased biosynthetic capacity of interrenal tissue with no effect on ACTH sensitivity. Comp. Biochem. Physiol. A 136, 613-620.

Scott, G.R., Sloman, K.A., Rouleau, C., Wood, C.M., 2003. Cadmium disrupts behavioural and physiological responses to alarm substance in juvenile rainbow trout (Oncorhynchus mykiss). J. Exp. Biol. 206, 1779-1790.

Sherwood, G.D., Rasmussen, J.B., Rowan, D.J., Brodeur, J., Hontela, A., 2000. Bioenergetic costs of heavy metal exposures in yellow perch (Perca flavescens): in situ estimates with a radiotracer $\left({ }^{137} \mathrm{Cs}\right)$ technique. Can. J. Fish Aquat. Sci. 59, 1-5.

Sloman, K.A., Scott, G.R., McDonald, D.G., Wood, C.M., 2004. Diminished social status affects ionoregulation at the gills and kidney in rainbow trout (Oncorhynchus mykiss). Can. J. Fish. Aquat. Sci. 61, 618-626.

Spear, P.A., Anderson, P.D., 1975. Fish size as a quantitative function of tolerance to heavy metals. Water Pollut. Res. Can. 10, 170-179.

Taylor, L.N., Wood, C.M., McDonald, D.G., 2003. An evaluation of sodium loss and gill metal binding properties in rainbow trout and yellow perch to explain species differences in copper tolerance. Env. Toxicol. Chem. 22, 2159-2166

Teles, M., Pacheco, M., Santos, M.A., 2005. Physiological and genetic responses of European eel (Anguilla anguilla L.) to short-term chromium or copper exposure-influence of preexposure to a PAH-like compound. Environ. Toxicol. 20, 92-99.

Van Heerden, D., Vosloo, A., Nikinmaa, M., 2004. Effects of short-term copper exposure on gill structure, metallothionein and hypoxia-inducible factor-1 alpha (HIF-1 alpha) levels in rainbow trout (Oncorhynchus mykiss). Aquat. Toxicol. 69, 271-280. 